\title{
Oligosaccharides of hyaluronan induce angiogenesis through distinct CD44 and RHAMM-mediated signalling pathways involving $\mathrm{Cdc} 2$ and $\gamma$-adducin
}

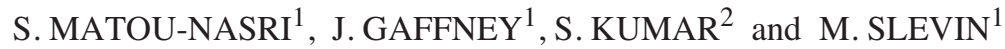 \\ ${ }^{1}$ School of Biology, Chemistry and Health Science, Manchester Metropolitan University, Manchester, M1 5GD; \\ ${ }^{2}$ Department of Pathology, Manchester University and Christie Hospital, Manchester, UK
}

Received March 11, 2009; Accepted May 7, 2009

DOI: 10.3892/ijo_00000389

\begin{abstract}
We used short-interfering RNA (siRNA) to knockdown the hyaluronan (HA) receptors CD44 and the receptor for hyaluronan-mediated motility (RHAMM) in vascular endothelial cells to investigate their role in angiogenesis. We showed that CD44 and RHAMM single knock-down inhibited low molecular weight hyaluronan (o-HA)-induced endothelial cell tube formation in Matrigel, but no change in the control, epidermal growth factor-induced tube formation was observed. Using a Kinexus phosphoprotein array and confirmational Western blotting we were able to show a differential effect on HA-induced protein expression after CD44 and RHAMM knockdown. CD44 knock-down abolished o-HA-induced membrane phospho-protein kinase $\mathrm{C}-\alpha(\mathrm{PKC}-\alpha)$ and downstream phospho- $\gamma$-adducin expression. Using the PKC inhibitor Go6976, we demonstrated the involvement of PKC- $\alpha$ and $\gamma$-adducin in o-HA-induced tube formation, whilst o-HA-induced enzymatic activity of MMP9 was also reduced. This suggests that endothelial tube formation involves activation of MMP9 via PKC- $\alpha$. Furthermore, the involvement of $\gamma$-adducin in o-HA-induced F-actin cytoskeleton rearrangement was CD44-dependent and the reduction of CD44 expression lead to a change in endothelial cell morphology. Both RHAMM and CD44 knockdown completely inhibited o-HA-induced Cdc2 (Cdk1) phosphorylation suggesting a possible involvement in cell cycle control. Although CD44 and RHAMM are both involved in
\end{abstract}

Correspondence to: Dr Mark Slevin, School of Biology, Chemistry and Health Science, Manchester Metropolitan University, Manchester M1 5GD, UK

E-mail: m.a.slevin@mmu.ac.uk

Abbreviations: BAEC, bovine aortic endothelial cells; ERK, extracellular-signal regulated kinase; MMP, matrix metalloproteinase; o-HA, oligosaccharides of hyaluronan; RHAMM, receptor for hyaluronan-mediated motility; $\mathrm{PKC}$, protein kinase $\mathrm{C}$; siRNA, small-interfering RNA

Key words: angiogenesis, endothelial cell, oligosaccharides of hyaluronan, CD44, RHAMM, siRNA, MMP-9, PKC, $\gamma$-adducin
o-HA-induced endothelial tube formation in Matrigel, they mediate distinct angiogenic signalling pathway and for the first time we demonstrated the specific involvement of $\gamma$-adducin in CD44/o-HA-induced endothelial tube formation. The data presented here extend our understanding of key stages of the processes of o-HA-induced angiogenesis which may have relevance to tumour progression.

\section{Introduction}

Angiogenesis, the formation of new blood vessels from the pre-existing vascular networks, is associated with both physiological (wound healing) and pathological processes (tumour progression). It is generally accepted that solid tumours are restricted in size by access to the vasculature and tumour expansion is accompanied by increased vascular proliferation (1). Hyaluronan (HA), a major component of connective tissue ECM, is a non-sulphated, negatively charged linear polymer of repeated disaccharide units of $B(1,4)-D$ glucuronic acid- $\beta(1,3) \mathrm{N}$-acetyl-D-glucosamine. HA has a mean relative molecular mass of $10^{3} \mathrm{kDa}$ and has antibacterial, anti-inflammatory and lubricant properties. HA has a differential effect on angiogenesis according to its size $(2,3)$. Native high molecular weight HA (n-HA) inhibits angiogenesis in vitro whereas oligosaccharides of HA (o-HA; 3-10 disaccharide units) stimulate angiogenesis both in vitro and in vivo in the chick chorioallantoic membrane assay and after myocardial infarction (4). In endothelial cells (EC), o-HA induces proteolytic activity (5), cell proliferation (6-9) and migration (9). It induces tube formation in collagen gels (10) and production and deposition of collagen in the formation of endothelial cords (11).

HA mediates its effects via the cell surface receptors CD44 and RHAMM (12). CD44 is a ubiquitous cell-surface glycoprotein involved in cell activation and in cell-cell and cellsubstrate interactions and cooperates with MMPs during cell migration $(13,14)$. It contains extracellular, transmembrane and short intracellular domains. The extracellular domain of CD44 is heterogeneous and subject to both $\mathrm{N}$ - and O-glycosylation, and contains an amino-terminal HA-binding motif (15). In response to hyaluronan binding the cytoplasmic tail of CD44 interacts with cytoskeletal proteins such as actin and regulatory and adaptator molecules such as ankyrin (16). 
CD44/o-HA interaction can stimulate EC proliferation by activation of signalling pathways which may involve tyrosine phosphorylation of the CD44 cytoplasmic tail followed by activation of protein kinase $\mathrm{C}$, and mitogen-activated protein kinase (extracellular signal-regulated kinase 1 and 2, ERK1/2) $(8,9)$ followed by early response gene activation $(7)$.

Although it is widely accepted that CD44 is the principal plasma membrane receptor for HA, the role of RHAMM is still undefined. RHAMM is alternatively spliced and different isoforms of the protein are found both on the cell surface and intracellularly (cytoplasm, cytoskeleton, mitochondria, nucleus and nucleolus) (17). Although RHAMM mRNA does not contain a recognizable leader sequence, the protein is transported to the cell surface, where it binds HA and transduces signals that influence growth and motility. Intracellular RHAMM interacts with several signalling and cytoskeletal proteins, including Src (18), actin and with microtubules (19) and regulates ERK activity (20). Interaction of HA with CD44 and RHAMM leads to numerous cellular responses, including activation of components of signalling pathways and cytoskeletal proteins (17). Although there is some evidence that CD44 and RHAMM can participate independently in proliferatiion and migration, their relative contributions to endothelial tube formation (i.e. cell differentiation) in response to o-HA have not been fully resolved.

Here we report the use of short-interfering RNA (siRNA) to down-regulate CD44 and RHAMM protein expression and the effect on o-HA-induced angiogenesis and associated signal transduction in vascular EC. As a control, we employed epidermal growth factor (EGF) which elicits an angiogenic response independent of hyaluronan receptors in bovine aortic EC (BAEC). We showed that both CD44 and RHAMM are involved in o-HA-induced endothelial tube formation in Matrigel. We also found that o-HA binding to CD44 resulted in PKC- $\alpha$ phosphorylation of $\gamma$-adducin a membrane cytoskeletal and actin-binding protein and a change of cell shape.

\section{Materials and methods}

Reagents. Dulbecco's modified Eagle's medium (DMEM) and foetal bovine serum (FBS) were obtained from BioWhittaker (Cambrex Bioscience, Verviers, Belgium). The following reagents were used: Brij 35, protein kinase C inhibitor (Go6976) and phalloidin-TRITC from Sigma-Aldrich (St Louis, MO), growth factor-reduced Matrigel (BectonDickinson Biosciences, San Jose, CA, USA), recombinant human epidermal growth factor (EGF, R\&D systems, Minneapolis, MN). Oligosaccharides of hyaluronan were prepared as previously described (9). The following antibodies were used: anti-CD44 monoclonal antibody (rat $\mathrm{IgG}_{2 \mathrm{~b}, \mathrm{\kappa}}$, clone IM7, anti-mouse/human ) purified or conjugated to phycoerythrin (BioLegend, San Diego, CA); anti-RHAMM (goat polyclonal IgG, clone E-19), anti-ERK1/2 (rabbit polyclonal); anti-phospho-ERK1/2 (Tyr 204, mouse monoclonal), anti- $\gamma$-adducin (goat polyclonal) were all from Santa Cruz Biotechnology (Heidelberg, Germany), antiphospho-PKC $\alpha$ (Ser 657, rabbit polyclonal) from Upstate Biotechnology (Lake Placid, NY), anti-phospho- $\gamma$-adducin (Ser 662, rabbit polyclonal) from Abcam (Cambridge, UK) and anti- $\alpha$-actin (rabbit polyclonal) from Sigma-Aldrich, UK.
Endothelial cell culture. EC were isolated from bovine aorta and characterised as endothelial as described previously (21). BAEC were grown in complete medium of DMEM supplemented with $15 \%$ FBS, $2 \mathrm{mM}$ glutamine, $100 \mathrm{U} / \mathrm{ml}$ penicillin and $100 \mu \mathrm{g} / \mathrm{ml}$ streptomycin. Cells were seeded into T75 flasks (Nunc) pre-coated with $0.1 \%$ gelatine and incubated in humidified $5 \% \mathrm{CO}_{2}$-air at $37^{\circ} \mathrm{C}$. Every three days, BAEC were passaged at a split ratio of $1: 2$ or $1: 3$ by treatment with $\mathrm{Ca}^{2+}$ and $\mathrm{Mg}^{2+}$ free PBS and cells detached by enzymatic digestion with $0.05 \%$ trypsin/0.02\% EDTA. BAEC were used between passages 4 and 10 .

Short-interfering RNA targeting CD44 and RHAMM. Shortinterfering RNA (siRNA) targeting bovine CD44 (CD44 siRNA) or RHAMM (RHAMM siRNA) were selected online from MWG biotech (MWG-biotech.com) from Bos taurus gene sequences encoding CD44 (GenBank access number: X62881) and RHAMM (GenBank access number: XM_ 590028). SiRNA sequences (Table I) were designed according to the methods of Elbashir et al (22) and synthesised by GenePharma (Shanghai, China). Negative control (NC) siRNA duplexes were included in all experiments with the sequences: 5'-UUCUCCGAACGUGUCACGUdTdT-3' (sense) and 5'-ACGUGACACGUUCGGAGAAdTdT-3' (antisense). Selected specific sequences were subjected to a BLAST search to ensure there was no significant homology with other genes. To examine the transfection efficiency, NC-FAM (negative control-fluorescein amino-modified oligonucleotides) siRNA was transfected into BAEC and the following day cells were washed with PBS, fixed with $4 \%$ PFA and visualised with a Zeiss fluorescent microscope. For mRNA 'knock-down', the reverse transfection method was applied as described by Elbashir et al (22). Briefly, siRNA duplexes at a final concentration of $50 \mathrm{nM}$ were transfected into BAEC (70-80\% confluent) cultured in 24- or 6-well plates. Cells were incubated at $37^{\circ} \mathrm{C}$ for $2 \mathrm{~h}$ before the addition of $10 \%$ FBS with $100 \mathrm{U} / \mathrm{ml}$ penicillin and $100 \mu \mathrm{g} / \mathrm{ml}$ streptomycin then cells cultured for a further 48-72 h.

$R N A$ extraction and $R T-P C R$. Total RNA was extracted using a modified protocol combining the cell lysis solution from SuperScript III Cellsdirect cDNA Synthesis System Invitrogen kit (Invitrogen, Carlsbad, CA) with DNase I from Cells-to-cDNA II-Ambion kit (Ambion, Cambridgeshire, UK). The amount of RNA was normalised to the number of cells. Briefly, the cell suspension in PBS $(2 \mu 1,8,000$ cells/ $\mu 1)$ was lysed with $1 \mu 1$ of lysis enhancer and $10 \mu 1$ of lysis buffer (Invitrogen kit) for $10 \mathrm{~min}$ at $75^{\circ} \mathrm{C}$. Cell lysates were kept on ice for $5 \mathrm{~min}$ then briefly vortexed. DNase I (Ambion) was added for $15 \mathrm{~min}$ at $37^{\circ} \mathrm{C}$, followed by $5 \mathrm{~min}$ at $75^{\circ} \mathrm{C}$ then RNA was collected. RT-PCR was used to monitor bovine CD44 and RHAMM mRNA and S14 housekeeping gene. All RT-PCR reagents were from Promega (Southampton, UK). Complementary DNA (cDNA) was produced from total RNA extracts as follows. First, total RNA samples were mixed with oligo $(\mathrm{dT})_{15}$ primers and $10 \mathrm{mM} \mathrm{dNTP}$ mix for $5 \mathrm{~min}$ at $70^{\circ} \mathrm{C}$. After $3 \mathrm{~min}$ on ice, reverse transcriptase, ribonuclease inhibitor, $5 \mathrm{X}$ reaction buffer, $\mathrm{MgCl}_{2}$ and nuclease-free water were added to the RNA samples. cDNA was polymerised at $50^{\circ} \mathrm{C}$ for $50 \mathrm{~min}$ followed by inactivation at $85^{\circ} \mathrm{C}$ for $5 \mathrm{~min}$. 
Table I. SiRNA sequences used for bovine CD44 and RHAMM knock-down gene expression.

\begin{tabular}{|c|c|c|c|c|}
\hline Target gene & $\begin{array}{l}\text { GenBank accession } \\
\text { number }\end{array}$ & siRNA sequences & $\begin{array}{l}\text { Distance from } \\
\text { start }\end{array}$ & $\% \mathrm{GC}$ \\
\hline CD44 & X62881 & $\begin{array}{l}\text { 5'-GGACCAAUUACCAUAACUAdTdT-3' (sense) } \\
\text { 5'-UAGUUAUGGUAAUUGGUCCdTdT-3' (antisense) }\end{array}$ & 418 & 36.8 \\
\hline RHAMM & XM_590028 & $\begin{array}{l}\text { 5'-AUACCAGGUGCUUGAAGAAdTdT-3' (sense) } \\
\text { 5'-UUCUUCAAGCACCUGGUAUdTdT-3' (antisense) }\end{array}$ & 909 & 42.1 \\
\hline
\end{tabular}

Table II. Bovine specific primer sequences and expected size of amplified products.

\begin{tabular}{lcc}
\hline Primers & Sequences & Size (bp) \\
\hline CD44f & 5'-CGGAAACCTCAAATTCCAGA-3' & 218 \\
CD44r & 5'-TTGTTCACCAAATGCACCAT-3' & 154 \\
RHAMMf & 5'-CAGCAAAAGGAGGAACAAGC-3' & \\
RHSAMMr & 5'-GCAGGGTGGCCTGAGTATAA-3' \\
S14f & 5'-GACATTTGCGGTCAACAAGA-3' \\
S14r & 5'-ATCCGTAGCCTCTCATCTGC-3' \\
\hline
\end{tabular}

All gene-specific primer pairs were optimized for cycle number (CD44 and S14 = 35 cycles, RHAMM = 40 cycles $)$ and $\mathrm{t}_{\mathrm{m}}\left(60^{\circ} \mathrm{C}\right)$. Primer pairs (Invitrogen) were selected by software Primer3 and the sequences are shown in Table II. Briefly, for each PCR reaction, $1 \mu \mathrm{l}$ of cDNA from reverse transcriptase reactions was mixed with $1 \mu 1$ of gene specific primers (forward and reverse each at $1 \mu \mathrm{M}$ ), $5 \mu 1$ of $2 \mathrm{X}$ Master Mix and $3 \mu \mathrm{l}$ of nuclease-free water. Amplification conditions were $10 \mathrm{~min}$ at $94^{\circ} \mathrm{C}$ and 35 (for CD44 or S14) or 40 (for RHAMM) cycles of $1 \mathrm{~min}$ at $94^{\circ} \mathrm{C} / 1 \mathrm{~min}$ at $60^{\circ} \mathrm{C} /$ $1 \mathrm{~min} 30$ at $72^{\circ} \mathrm{C}$ then $10 \mathrm{~min}$ at $72^{\circ} \mathrm{C}$. PCR products were separated by $1.5 \%$ agarose gel electrophoresis. Bovine ribosomal protein S14 expression was used as an internal standard.

Immunofluorescent staining. Cells $\left(1.2 \times 10^{5}\right.$ cells/500 $\left.\mu 1\right)$ transfected with $50 \mathrm{nM}$ of CD44, RHAMM or NC siRNA or untransfected cells were seeded in Lab-Tek chamber slides (Nunc-Scientific Laboratory Supplies, Nottingham, UK). After $72 \mathrm{~h}$, cells were washed (2X with PBS), fixed with $4 \%$ PFA for $10 \mathrm{~min}$ and in the case of RHAMM, permeabilised with $0.1 \%$ Triton $\mathrm{X}-100$ in PBS for $10 \mathrm{~min}$. The cells were then washed (2X in PBS for $5 \mathrm{~min}$ ). After blocking (PBS-1\% BSA for $30 \mathrm{~min}$ ) cells were incubated with phycoerythrin (PE) anti-CD44 antibody (1:25) or with anti-RHAMM antibody (1:50) diluted in PBS-1\% BSA for $1 \mathrm{~h}$ at RT. In the case of RHAMM, cells were washed with PBS (3X) and incubated for a further $1 \mathrm{~h}$ with rabbit anti-goat antibody (1:50) conjugated to Alexa Fluor 488 (Molecular Probes-Invitrogen, Paisley, UK) at RT. After washing with PBS, the chamber slides were mounted with Vectashield aqueous mounting medium and the proteins localised using a fluorescent microscope.
Tube formation assay. Cells (40 $\mu 1,2 \times 10^{6}$ cells $\left./ \mathrm{ml}\right)$ transfected with CD44, RHAMM or NC siRNA or untransfected cells were mixed with an equal volume of growth factor-reduced Matrigel $(40 \mu 1,10 \mathrm{mg} / \mathrm{ml})$ with or without o-HA $(0.5 \mu \mathrm{g} / \mathrm{ml})$ or with EGF $(10 \mathrm{ng} / \mathrm{ml})$. To investigate the role of PKC, untransfected cells were treated with the PKC inhibitor Go6976 (10-20 nM) for $24 \mathrm{~h}$ before addition of Matrigel \pm o-HA. After polymerization ( $48 \mathrm{~h}$ in a 48 -well plate) complete medium $(500 \mu \mathrm{l})$ was added and the plate incubated for $24 \mathrm{~h}$. Cells were then fixed with $4 \%(\mathrm{w} / \mathrm{v})$ PFA for $10 \mathrm{~min}$. Tube formation was quantified by counting the number of closed areas in each well in a blind fashion $(23,24)$. All experiments were carried out in duplicate and repeated at least three times.

Gelatine zymography. Matrix metalloproteinase activities were evaluated in the medium of cells $72 \mathrm{~h}$ after transfection with siRNA (in 24-well plates) or after a further $24 \mathrm{~h}$ in Matrigel (in 48-well plates). The medium was collected and centrifuged $\left(1,600 \mathrm{rpm}\right.$ for $15 \mathrm{~min}$ at $\left.4^{\circ} \mathrm{C}\right)$. Protein concentration was determined using the Bradford protein assay (Bio-Rad, Munchen, Germany), and the samples (50 $\mu \mathrm{g}$ of protein) were mixed with an equal volume of non-reducing sample buffer. The samples were incubated $(10 \mathrm{~min}, \mathrm{RT})$ and subject to electrophoresis on $7.5 \%$ SDS-PAGE gels containing $1 \mathrm{mg} / \mathrm{ml}$ gelatine as a substrate. The gels were rinsed in renaturation buffer (2.5\% Triton X-100) for $30 \mathrm{~min}$ at RT followed by activation buffer ( $50 \mathrm{mM}$ Tris- $\mathrm{HCl}, 0.2 \mathrm{M}$ $\mathrm{NaCl}, 5 \mathrm{mM} \mathrm{CaCl}_{2}$ and $0.02 \%$ Brij 35) for $30 \mathrm{~min}$. Gels were incubated overnight at $37^{\circ} \mathrm{C}$ with fresh activation buffer then stained with $0.5 \%$ Coomassie blue R-250 for $2 \mathrm{~h}$. After destaining, MMP gelatinase activity was detected as a white 
A

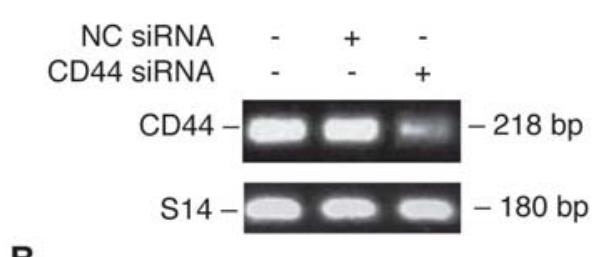

B

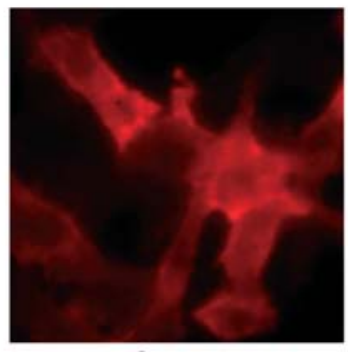

Control

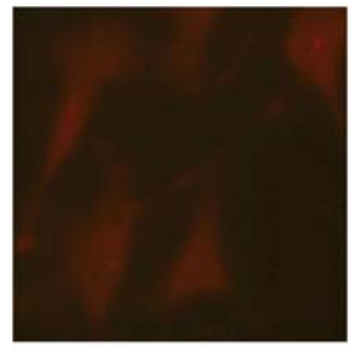

CD44 siRNA

C

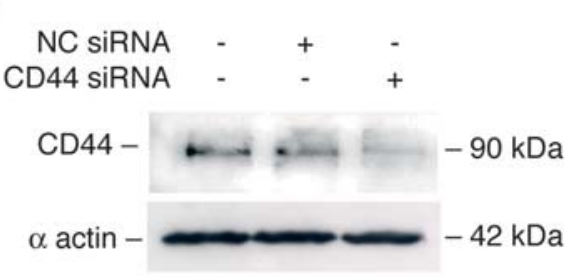

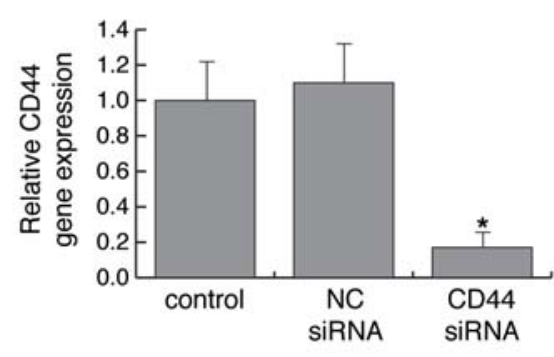

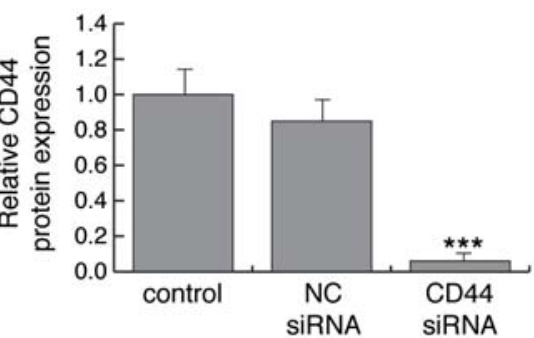

Figure 1. Transfection with CD44 siRNA inhibited gene and protein expression in BAEC. BAEC were transfected with NC or CD44 siRNA for 48 h as described. RT-PCR showed decreased CD44 expression compared to NC siRNA control cells (A). Gene expression was expressed relative to control cells, assigned an arbitrary value of 1.0 and with S14 as a loading control. Immunofluorescent staining of BAEC (B) was determined with a CD44 antibody conjugated to phycoerythrin and showed CD44 expression was decreased in cells transfected for $72 \mathrm{~h}$ with CD44 siRNA (original magnification, $\mathrm{x} 100$ ) compared to the control. Western blot analysis showed a reduction in CD44 protein expression after knockdown compared with control cells (C). Values are expressed relative to the control assigned an arbitrary value of 1.0 and with $\alpha$-actin as a loading control. Data are means \pm SD from three independent experiments and * and $^{* * *}$ signify a statistically significant difference compared to the control $(\mathrm{p}<0.05$ and $\mathrm{p}<0.01)$.

band on a dark blue background and quantified by densitometry using Image $\mathbf{J}$ software.

Western immunoblot analysis. Cells were seeded in 6-well $\left(3 \times 10^{5}\right.$ cells $\left./ 1.8 \mathrm{ml}\right)$ or 24 -well plates $\left(2.5 \times 10^{5}\right.$ cells $\left./ 450 \mu \mathrm{l}\right)$ and transfected with CD44, RHAMM (200 $\mu 1$ or $50 \mu 1$, respectively) or NC siRNA (50 nM). After $48 \mathrm{~h}$ incubation, serum-free medium was added and cells incubated for $48 \mathrm{~h}$. o-HA $(1 \mu \mathrm{g} / \mathrm{ml})$ or EGF $(10 \mathrm{ng} / \mathrm{ml})$ was added $\left(7 \mathrm{~min}\right.$ at $\left.37^{\circ} \mathrm{C}\right)$. After washing in cold PBS, cells were agitated $\left(4^{\circ} \mathrm{C}, 1 \mathrm{~min}\right)$ in ice-cold RIPA buffer. Total cell lysates were collected and stored at $-20^{\circ} \mathrm{C}$. Cell fractionation was performed as described previously (9) and equal quantities of proteins from total cell lysates $(30 \mu \mathrm{g})$ and each cellular fraction (10-15 $\mu \mathrm{g})$ were mixed with $2 \mathrm{X}$ Laemmli sample buffer, vortex mixed and boiled in a water bath for $15 \mathrm{~min}$. Samples were separated along with pre-stained molecular weight markers (27-180 kDa, Sigma, UK) by $12 \%$ SDS-PAGE. Proteins were electroblotted (Hoefer Scientific Instruments, San Francisco, USA) onto nitrocellulose filters $(1 \mathrm{~h})$ and the filters were blocked for $(1 \mathrm{~h}$, RT) in TBS-Tween ( $\mathrm{pH} 7.4$ ) containing 1\% BSA. Filters were stained with primary antibodies to CD44 (1:250), RHAMM (1:500), ERK1/2 (1:1000), phospho-ERK1/2 $(1: 1000), \gamma$-adducin $(1: 200)$, phospho- $\gamma$-adducin (Ser 662)
(1:1000), phospho-PKC- $\alpha$ (Ser 657) (1:1000) and $\alpha$-actin (1:1000) diluted in the appropriate blocking buffer, overnight at $4^{\circ} \mathrm{C}$ on a rotating shaker. After washing (5x10 min in TBSTween at RT) filters were stained with the appropriate horseradish peroxidase-conjugated secondary antibodies (DakoCytomation, Glostrup, Denmark) diluted in TBSTween containing 5\% de-fatted milk $(1: 2000,1 \mathrm{~h})$ with continuous mixing. Proteins were visualized using ECL and hyperfilm X-ray film RPN 2103 K (Amersham, Buckinghamshire, UK).

To assess the efficiency of PKC inhibition, un-transfected cells were treated for $24 \mathrm{~h}$ followed by cell fractionation and membrane phospho-PKC- $\alpha$ and of phospho- $\gamma$-adducin were measured.

Kinexus phospho-protein array analysis. Cells $\left(3 \times 10^{5}\right.$ cells/ $2 \mathrm{ml}$ in complete medium) were seeded in 6-well plates. After $48 \mathrm{~h}$ the medium was replaced with SFM and after a further $48 \mathrm{~h}, \mathrm{o}-\mathrm{HA}(1 \mu \mathrm{g} / \mathrm{ml})$ was added and the cells incubated for $7 \mathrm{~min}$. To evaluate the expression of signalling proteins downstream of hyaluronan receptors, a phospho-protein array analysis (Kinetworks PhosphoSite Screen, KPSS-1.3) was performed by Kinexus Bioinformatics (Vancouver, Canada). Proteins from o-HA-stimulated and un-stimulated cells were 
A

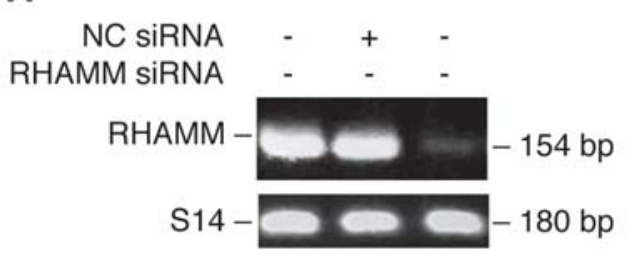

B

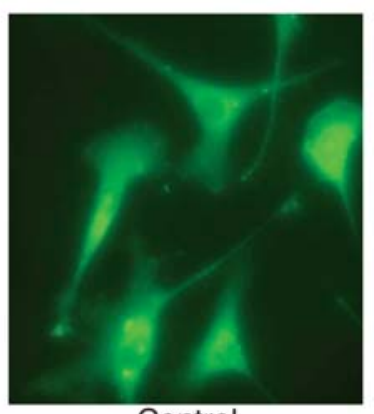

Control

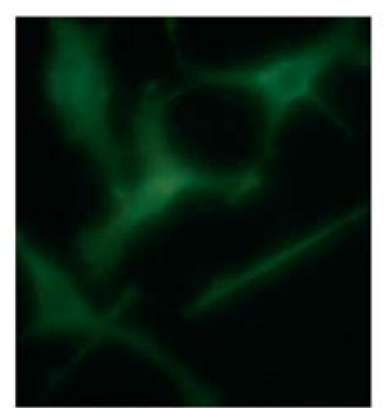

RHAMM SiRNA

C

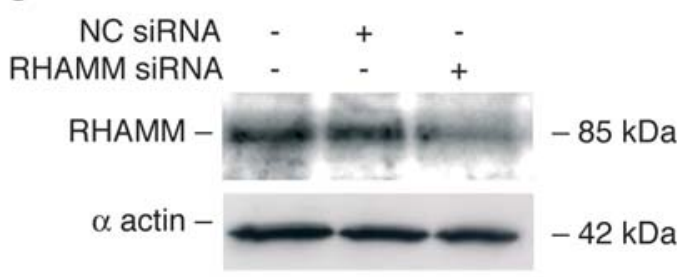

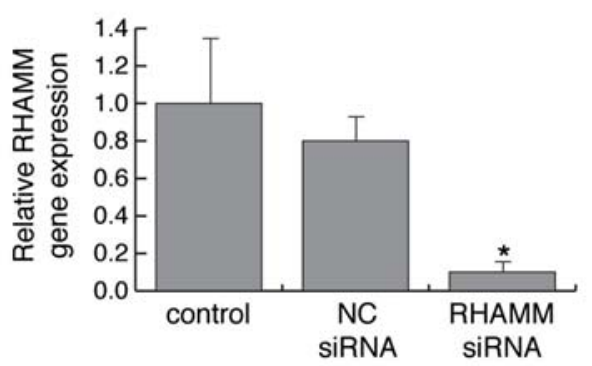

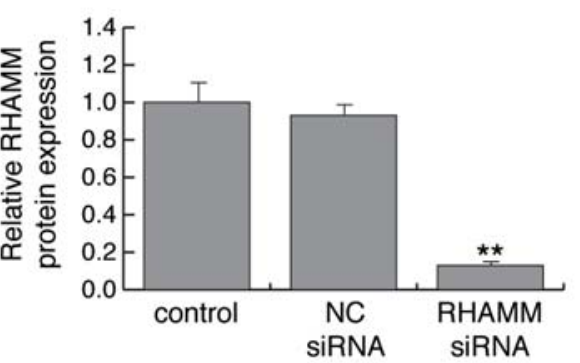

Figure 2. Transfection with siRNA inhibited RHAMM gene and protein expression in BAEC. BAEC were transfected with NC or RHAMM siRNA for $48 \mathrm{~h}$ as described. RT-PCR showed decreased RHAMM expression compared to NC siRNA control cells. Gene expression was expressed relative to the control assigned an arbitrary value of 1.0 and S14 was use as a loading control. (B) Immunofluorescent staining of BAEC with RHAMM antibody and with a secondary antibody conjugated to Alexa Fluor 488 showed intracellular, perinuclear and nuclear localisation after permeabilisation with $0.1 \%$ Triton X-100 (original magnification, x100). The staining of RHAMM expressed in the cytoplasm of non-transfected cells was decreased $72 \mathrm{~h}$ after transfection with RHAMM siRNA. Western blot analysis showed a significant reduction in RHAMM expression after knockdown compared with control cells. Values expressed relative to control cells assigned an arbitrary value of 1.0 and with $\alpha$-actin was a loading control. Data are means \pm SD from three independent experiments and $^{*}$ and ${ }^{* *}$ signify a statistically significant difference compared to the control $(\mathrm{p}<0.05$ and $\mathrm{p}<0.01)$.

extracted according to the manufacturer's instructions. The samples were used for a multi-immunoblotting assay based on SDS-polyacrylamide minigel electrophoresis with 20-lane multi-immunoblotters using different primary antibodies. Proteins were quantified using chemiluminescence and relative expression was determined by Kinexus and expressed in normalized counts per min (cpm).

Immunofluorescent staining of phospho- $\gamma$-adducin and delivery of anti- $\gamma$-adducin antibody. Cells $\left(1.2 \times 10^{5}\right.$ cells/ $500 \mu 1$ ) transfected with CD44 or NC siRNA (50 nM in each case) or un-transfected cells were seeded on glass coverslips in 24-well plates for $48 \mathrm{~h}$ in serum-free medium. Cells were then treated with o-HA $\left(1 \mu \mathrm{g} / \mathrm{ml}\right.$ for $7 \mathrm{~min}$ at $\left.37^{\circ} \mathrm{C}\right)$ washed in PBS, fixed with $4 \%$ PFA and permeabilised with $0.1 \%$ Triton X-100 in PBS for 10 min. After incubation with PBS$1 \%$ BSA for $30 \mathrm{~min}$, cells were treated with anti-phospho- $\gamma$ adducin antibody (1:50, $1 \mathrm{~h}$ at RT), washed and mouse antirabbit antibody conjugated to Alexa Fluor 488 (1:50, $1 \mathrm{~h}$ at RT) was added. To demonstrate a co-localisation of phospho$\gamma$-adducin in the cytoskeleton, F-actin was stained with
phalloidin-TRITC and nuclei stained with DAPI included in Vectashield aqueous mounting medium (Dako). Photomicrographs were taken using a Leica SP5 confocal fluorescent microscope.

To deliver anti- $\gamma$-adducin antibody to BAEC, PULSin ${ }^{\mathrm{TM}}$ (Autogen Bioclear, Wiltshire, UK) was used according to the manufacturer's instructions. Briefly, cells $\left(1.8 \times 10^{5} / 500 \mu 1\right.$ per well) were seeded in a 24 -well plate in complete medium and reached about $80 \%$ confluence the following day. The medium was replaced with $900 \mu 1$ of DMEM and $100 \mu 1$ of complexes composed of $1 \mu \mathrm{g}$ of anti- $\gamma$-adducin antibody diluted in $20 \mathrm{mM}$ Hepes and $3 \mu 1$ of PULSin. After incubation $(4 \mathrm{~h})$, the medium was replaced with fresh complete medium. To determine the efficiency of reagent delivery an antibody conjugated to R-phycoerythrin was used. After $48 \mathrm{~h}$ incubation, cells seeded on glass coverslips were washed with PBS, fixed with $4 \%$ PFA and visualised with a Zeiss fluorescence microscope. From 48 to 72 hours after intracellular delivery of anti- $\gamma$-adducin antibody, cells were used to study the effect of $\mathrm{o}-\mathrm{HA}$ on cell migration, proliferation and tube formation as described above. 
A
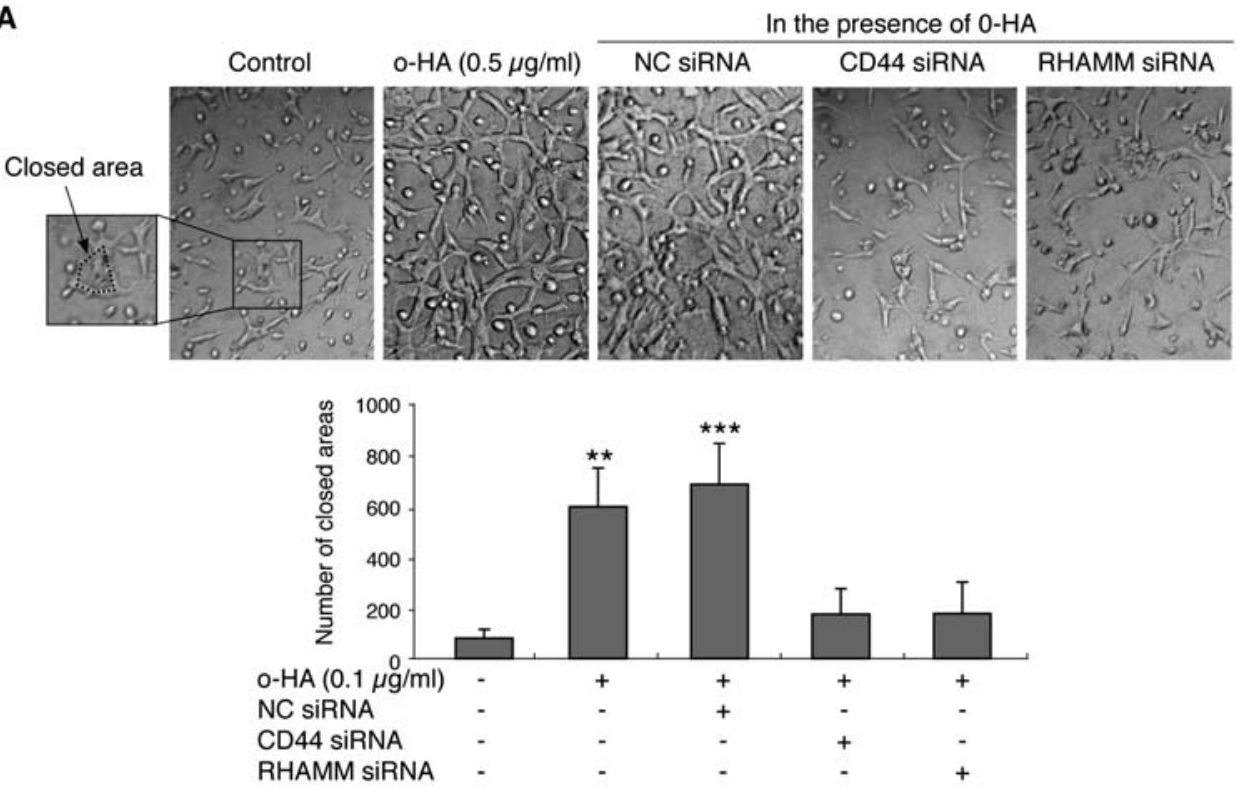

B
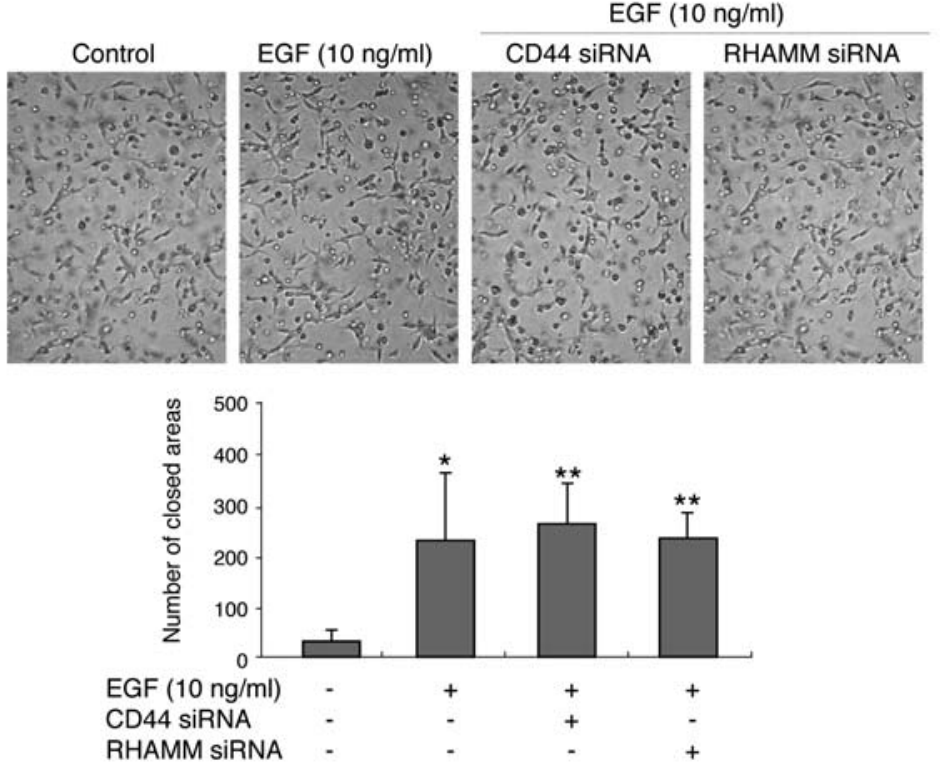

Figure 3. o-HA induced endothelial tube formation in Matrigel after CD44 or RHAMM knock-down. (A) Cells (40 $\mu 1,2 \times 10^{6}$ cells/ml) transfected with CD44, RHAMM or NC siRNA or un-transfected cells were mixed with an equal volume of growth factor-reduced Matrigel with or without o-HA (0.5 $\mu \mathrm{g} / \mathrm{ml})$. Tube formation was determined as described. Representative photomicrographs (original magnification, x100) showed o-HA induced formation of a capillarylike network in Matrigel compared to the control. CD44 or RHAMM knock-down significantly decreased o-HA-induced tube formation compared to untransfected control or NC siRNA-treated cells (B) EGF-induced tube formation was independent of CD44 or RHAMM. Representative photomicrographs (original magnification, $\mathrm{x} 100)$ showed that EGF $(10 \mathrm{ng} / \mathrm{ml})$ induced weak endothelial tube formation in Matrigel compared to the control. EGF was proangiogenic in BAEC transfected with CD44 or RHAMM siRNA. Data are expressed as the total number of closed areas and the values represent the means \pm SD of three experiments. * and ${ }^{* *}$ signify a statistically significant difference $(\mathrm{p}<0.05$ and $\mathrm{p}<0.01)$ compared to control.

Statistical analysis. All experiments were performed at least three times and the results are expressed as the mean \pm SD. Statistical significance was tested by Student's t-test and data were considered significant when $\mathrm{p} \leq 0.05$.

\section{Results}

Optimisation of siRNA knock-down of CD44 or RHAMM gene and protein expression. The efficiency of siRNA transfection determined using FAM fluorescein-conjugated negative control (NC) siRNA was almost $100 \% 24 \mathrm{~h}$ after transfection and cells were approximately $98 \%$ viable as determined by trypan blue exclusion (data not shown).
A similar expression of CD44 in BAEC and NC control siRNA-treated cells was demonstrated by RT-PCR. After $48 \mathrm{~h}$ transfection a significant decrease of CD44 expression (80\%; p=0.013; Fig. 1A) was observed. Immunofluorescent staining confirmed CD44 localisation on the plasma membrane with strongest staining at cell junctions (Fig. 1B). No staining was observed after treatment of BAEC with CD44 siRNA for 72 h. A significant down-regulation of CD44 protein (95\%; $\mathrm{p}<0.01$ ) was confirmed by Western blotting after $72 \mathrm{~h}$ compared with NC siRNA-treated or control cells (Fig. 1C).

Cells transfected with RHAMM siRNA showed a significant decrease of RHAMM expression after $48 \mathrm{~h}$ (95\%; $\mathrm{p}=0.016)$ compared to untransfected and NC siRNA-treated 
A
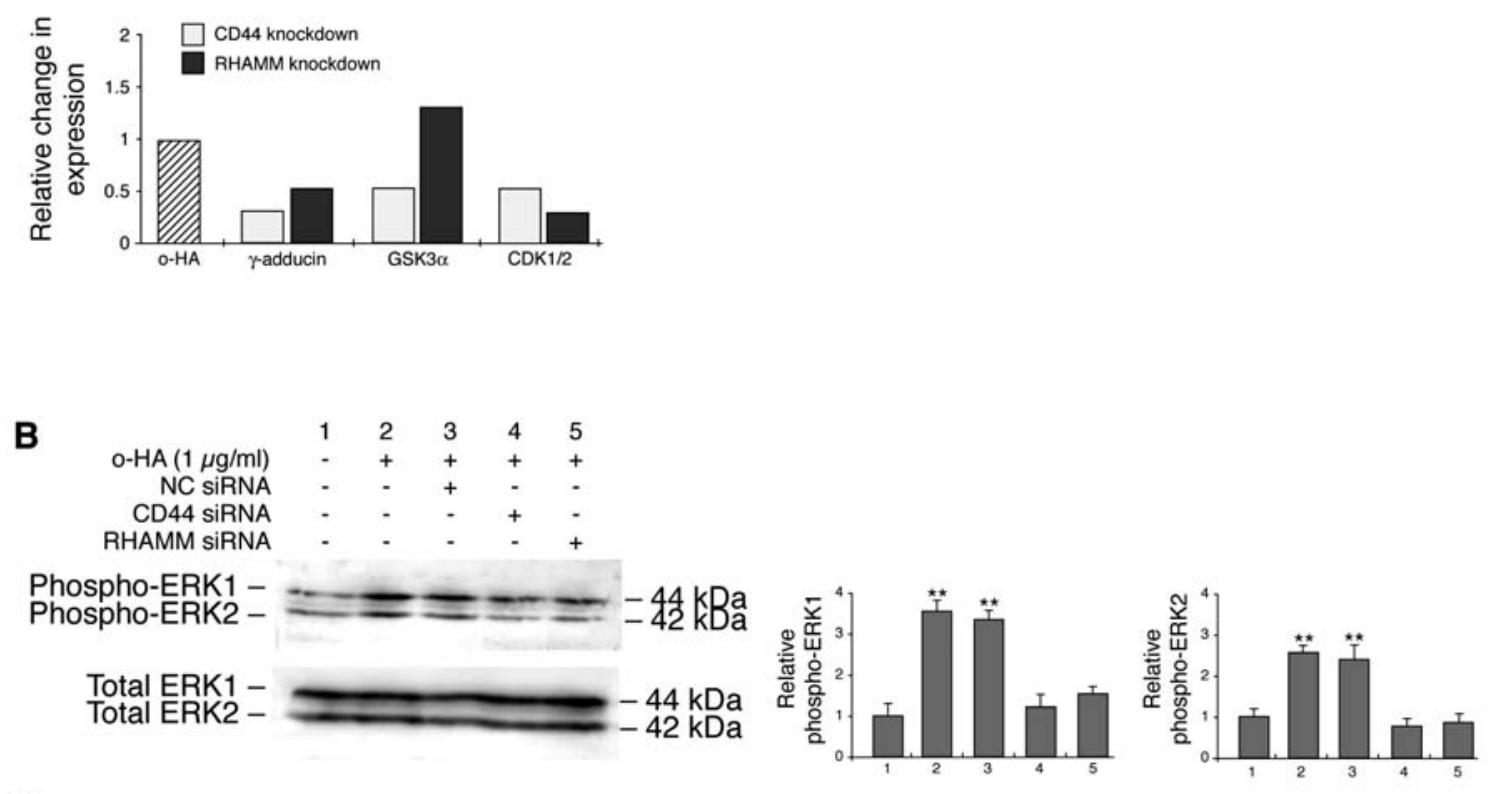

C

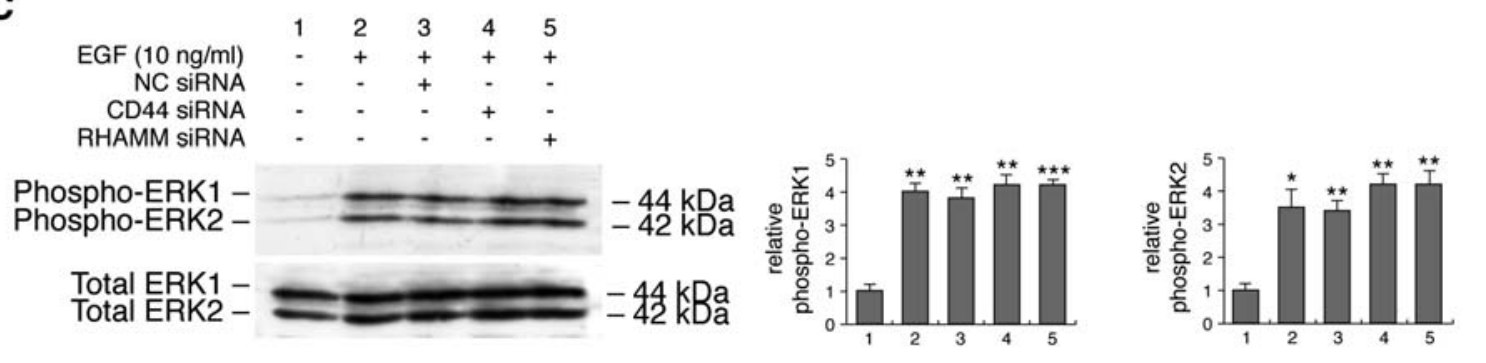

D
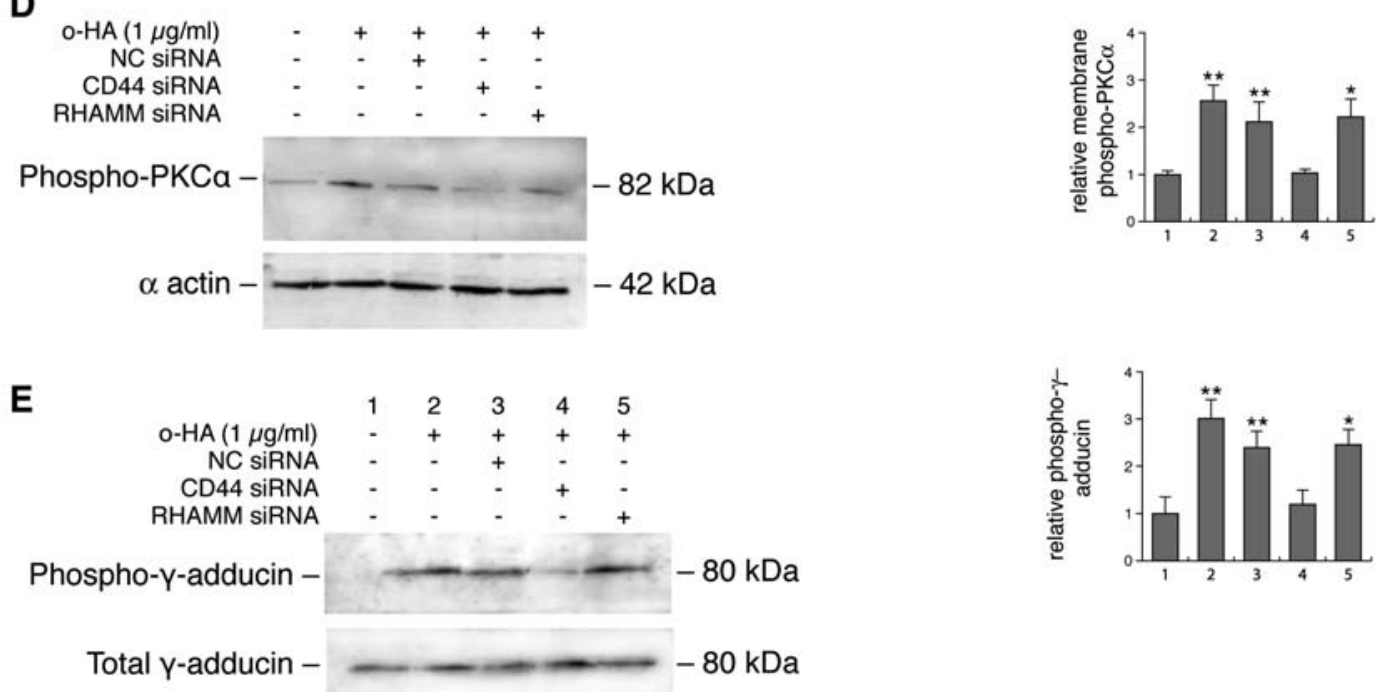

Figure 4. The role of CD44 and RHAMM in o-HA-induced signalling pathways. (A) Histogram showing Kinexus analysis of selected phosphoprotein expressions in o-HA treated cells. The accompanying histogram shows relative phosphoprotein expression compared to o-HA control cells (assigned a value of 1.0) and normalised to the expression of housekeeping proteins. (B) CD44 or RHAMM knock-down reduced o-HA-induced phospho-ERK expression. A representative Western blot showed a significant decrease of o-HA-induced phospho-ERK1/2 expression in both o-HA-stimulated CD44 and RHAMM siRNA-treated cells. Expression of phospho-ERK1/2 are shown relative to the control given a value of 1.0 and (**) signifies a statistically significant difference $(\mathrm{p}<0.01)$. (C) There was no change in EGF-induced phospho-ERK expression after CD44 or RHAMM knock-down. A representative Western blot shows unchanged phospho-ERK1/2 expression in EGF-stimulated CD44 and RHAMM siRNA-treated cells. Protein expression is shown relative to the control given a value of 1.0 and. ${ }^{* * *}$ and ${ }^{* * * *}$ signify a statistically significant difference relative to the control ( $<<0.05, \mathrm{p}<0.01$ and $\mathrm{p}<0.001$, respectively). o-HAinduced phosphorylation of PKC $\alpha$ (D) and $\gamma$-adducin (E) are mediated through CD44. Representative Western blots showing significant decreases of o-HAinduced membrane bound phospho-PKC- $\alpha$ and phospho- $\gamma$-adducin expression in o-HA-stimulated CD44 siRNA-treated cells but not in RHAMM siRNAtreated cells. Phospho-protein expression of membrane bound PKC $\alpha$ or $\gamma$-adducin shown relative to the control given a value of 1.0 and ${ }^{*}$ and ${ }^{* *}$ signify a statistically significant difference $(\mathrm{p}<0.05$ and $\mathrm{p}<0.01$, respectively) compared to the control. 
A

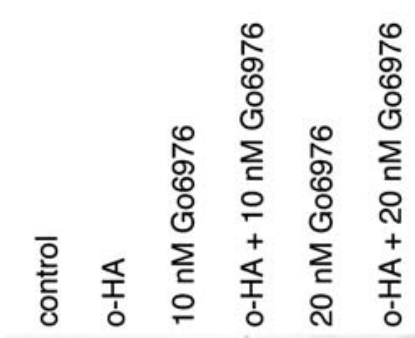

Phospho-PKCa-

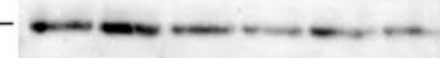

$-82 \mathrm{kDa}$

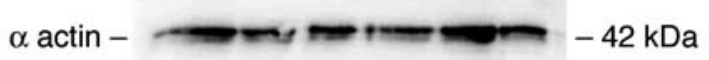

B

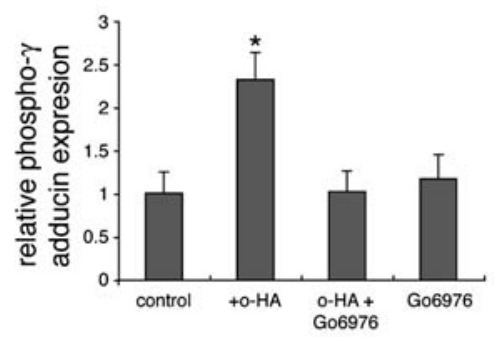

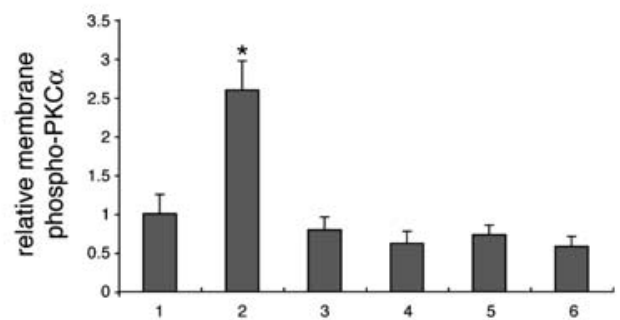

Figure 5. Inhibition of PKC using Go6976 reduced o-HA-induced phosphorylation of $\gamma$-adducin. BAEC were treated with Go6976 (10-20 $\mu \mathrm{M})$ with or without o-HA as described. A representative Western blot showed decreased o-HA-induced membrane bound phospho-PKC- $\alpha$ after $24 \mathrm{~h}$ treatment with Go6976 (A). Phospho-protein expression of membrane bound PKC- $\alpha$ is shown relative to the control given a value of 1.0. *Signifies a statistically significant difference $(\mathrm{p}<0.05)$ compared to control. (B) Bar chart showing a significant increase of o-HA-induced phospho- $\gamma$-adducin after $24 \mathrm{~h}$ treatment. This increase was abolished after treatment with Go6976 (10 nM). Values are expressed relative to the control value (assigned a value of 1.0) and determined by Western blotting. *Signifies a statistically significant difference $(\mathrm{p}<0.05)$ compared to control.

A
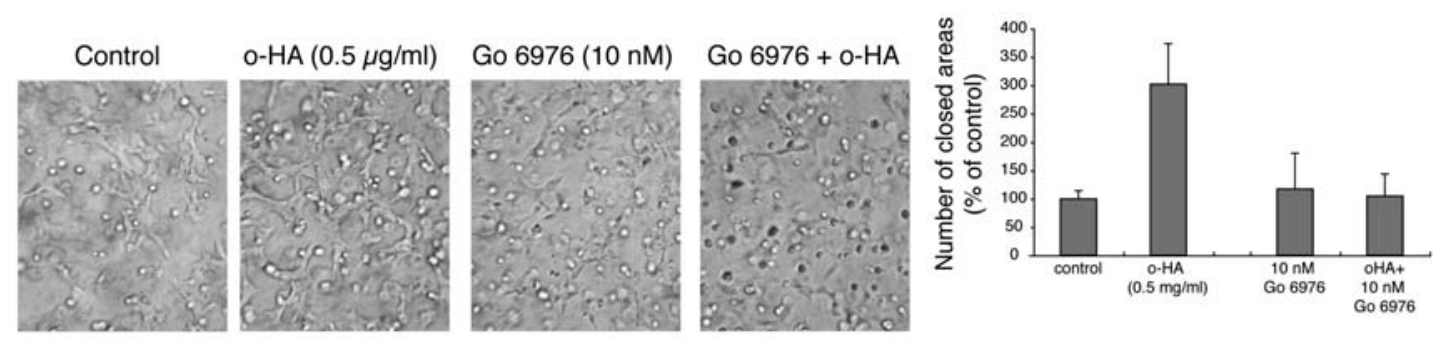

B
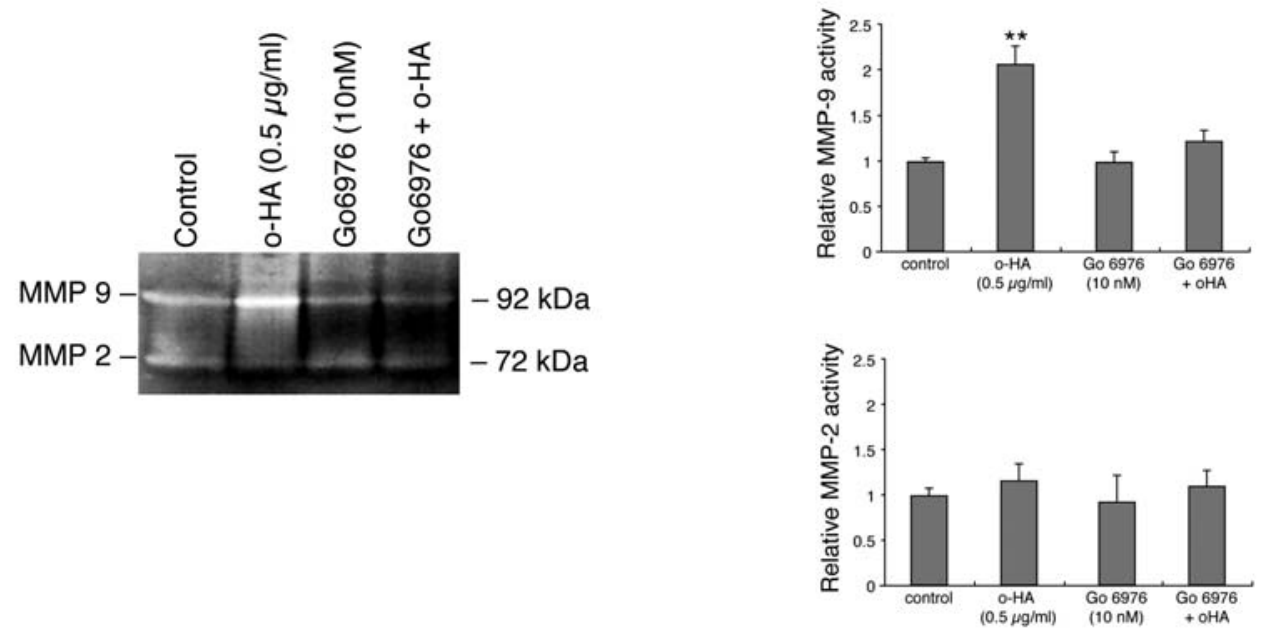

Figure 6. Inhibition of PKC- $\alpha$ reduced o-HA-induced endothelial tube formation in Matrigel and o-HA-induced MMP-9 activation. (A) Cells were treated with Go6976 (10 nM) $24 \mathrm{~h}$ before mixing with Matrigel. Tube formation was measured as described (section 2.6). Representative photomicrographs (original magnification, x100) showed inhibition of o-HA-induced tube formation by the addition of Go6976 (10 nM) compared to the control (Go6976 alone). Bar graphs represent the means \pm SD of three experiments. ${ }^{*}$ Signifies a statistically significant difference $(\mathrm{p}<0.01)$ compared to control. (B) Representative gelatine zymogram showing Go6976 inhibited o-HA-induced MMP-9 activity, compared to control cells or Go6976 alone. MMP-2 activity remained constant. Bands were analyzed by densitometry and normalized to the control given a value of 1.0. Values of MMP-9 or MMP-2 activity represent the means \pm SD of three experiments. ${ }^{* *}$ Signifies a statistically significant difference $(\mathrm{p}<0.01)$ from the control. 
cells (Fig. 2A). Weak expression of RHAMM protein was demonstrated by immunofluorescent staining on the cell surface (data not shown). Permeabilisation of the EC plasma membrane with $0.1 \%$ Triton $\mathrm{X}-100$ resulted in increased RHAMM distribution in peri-nuclear and nuclear regions (Fig. 2B). The knock-down of RHAMM resulted in decreased expression on the cell surface and intracellular before (data not shown) and after permeabilisation with Triton X-100 (Fig. 2B). Western blotting confirmed RHAMM knockdown ( $90 \%$ decrease; $p=0.01$ ) compared to control and NC siRNAtreated cells (Fig. 2C).

CD44 or RHAMM knock-down inhibited o-HA-induced endothelial tube formation in Matrigel. BAEC treated with $\mathrm{o}-\mathrm{HA}$ in Matrigel for $24 \mathrm{~h}$ showed increased formation of capillary-like networks $(8.5$-fold; $\mathrm{p}=0.003)$ compared to the control. No decrease of o-HA-induced tube formation was observed with NC siRNA-treated cells but there was a significant decrease after CD44 or RHAMM single knock-down (approximately $72 \%$ in each case) compared to o-HA alone (Fig. 3A).

To confirm the specificity of knock-down on tube formation the effect of EGF was examined since it exerts a pro-angiogenic effect independent of the o-HA pathway. Addition of EGF significantly increased tube formation (3.9-fold; $p=0.006$ ) and this was not affected by CD44 or RHAMM siRNA treatment (Fig. 3B). This data indicates that both CD44 and RHAMM mediate o-HA-induced endothelial tube formation.

Analysis of o-HA-induced protein phosphorylation. Using a Kinexus phospho-protein screen array the expression of phospho-proteins in samples obtained from lysates of unstimulated and o-HA-stimulated cells were analysed. Addition of o-HA significantly increased the expression of the phosphorylated forms of $\gamma$-adducin, cyclin-dependent kinase 1 $(\operatorname{cdk} 1 / \mathrm{Cdc} 2), \mathrm{PKC}-\alpha$, glycogen synthase serine kinase $3 \alpha$ (GSK-3 $\alpha$ ) and ERK1/2 compared to control cells and the expression was reduced after CD44 or RHAMM knockdown (Fig. 4A). We have previously reported the expression of specific o-HA-induced signalling components including ERK1/2 and membrane translocation of PKC- $\alpha$ resulting in BAEC proliferation and wound healing (9). Here, we examined the expression of these proteins $7 \mathrm{~min}$ after treatment with oHA: ERK1/2 was expression was used as a confirmation of the experimental procedure. An increased expression of phospho-ERK 1 and 2 was observed in o-HA treated cells (3.5- and 2.5-fold; $p=0.0047$ and $p=0.0035$, respectively) and expression was decreased in CD44 and RHAMM siRNAtreated cells (approximately $75 \%$ in each case; Fig. 4B). EGF treatment increased phospho-ERK1/2 expression (4.0-fold; $\mathrm{p}<0.05)$ compared to control cells and this was not perturbed after CD44 and RHAMM knock-down (Fig. 4C).

o-HA significantly increased membrane bound phosphoPKC- $\alpha$ expression compared to control cells $(2.5$-fold; $\mathrm{p}=0.0014$; Fig. 4D) and expression was completely abolished after CD44 knockdown but no significant change was observed in RHAMM siRNA-treated cells. Addition of o-HA increased phospho- $\gamma$-adducin expression compared to un-stimulated control cells (3.0-fold; Fig. 4E). The effect was almost

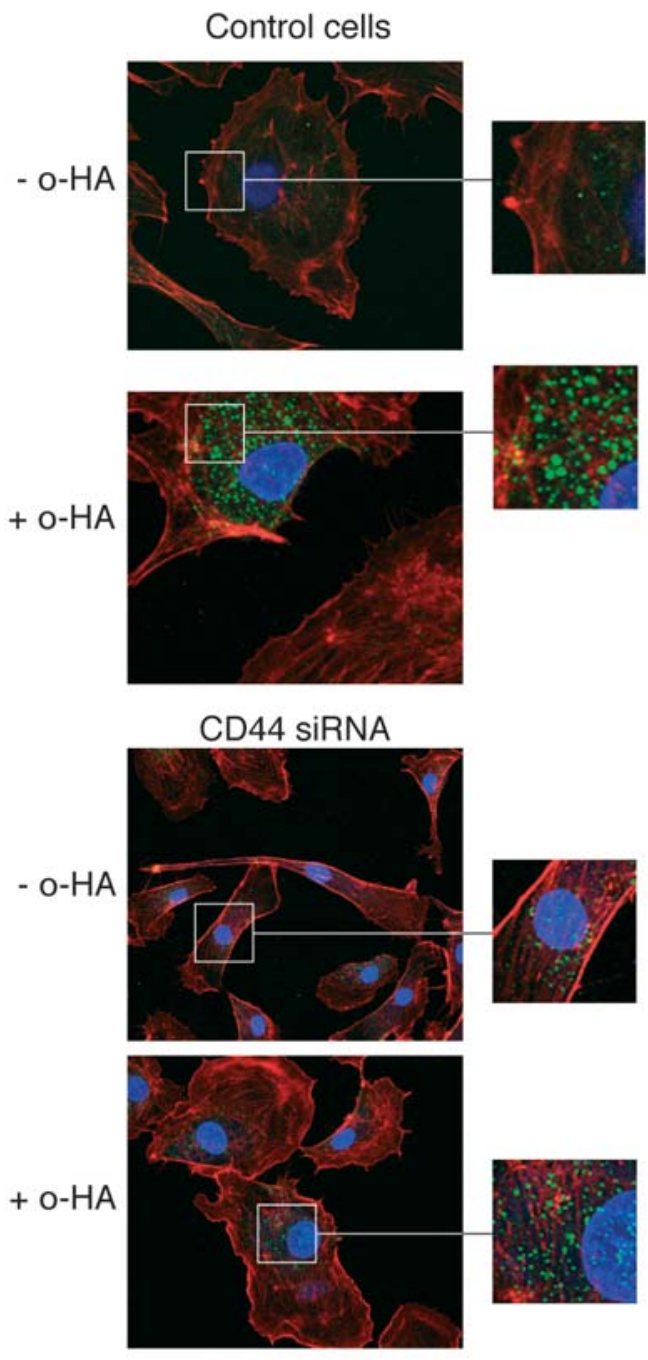

Figure 7. Involvement of CD44/phospho- $\gamma$-adducin in o-HA-induced F-actin cytoskeleton rearrangement. Cells knocked down with CD44 or RHAMM siRNA were exposed to o-HA and stained with anti-phospho- $\gamma$-adducin as described. Representative confocal photomicrographs (original magnification, $\mathrm{x} 400$ ) and insert (x630) showed a diffuse and peri-nuclear (blue) distribution of phospho- $\gamma$-adducin (green) in un-transfected cells in the absence of o-HA. The organization of F-actin stress fibres (red) gave cells a triangular shape. CD44 knockout cells showed an elongated shape with a rearrangement of F-actin stress fibres organized in parallel. After addition of o-HA increased staining for phospho- $\gamma$-adducin was observed with a peri-nuclear distribution and F-actin stress fibres were more pronounced. CD44 knockout cells showed a general reduction in fluorescent staining of phospho- $\gamma$-adducin and a disappearance of F-actin stress fibres.

completely abolished in CD44 siRNA-treated cells, whilst no significant change was observed in RHAMM siRNA-treated cells.

Role of PKCa in phospho- $\gamma$-adducin expression and in o-HAinduced tube formation and regulation of MMP-9 activity. To investigate a connection between the phosphorylation of $\gamma$-adducin and PKC $\alpha, \mathrm{BAEC}$ were treated with the PKC inhibitor (Go6976), whose effect on BAEC in the presence of o-HA we have previously reported (9). Go6976 (10 and $20 \mathrm{nM}$ ) significantly reduced o-HA-induced phosphorylation of PKC- $\alpha$ compared to the control (Fig. 5A). In addition inhibition of o-HA-induced phospho- $\gamma$-adducin was also observed with Go6976 (10 nM) (Fig. 5B). After demonstrating 

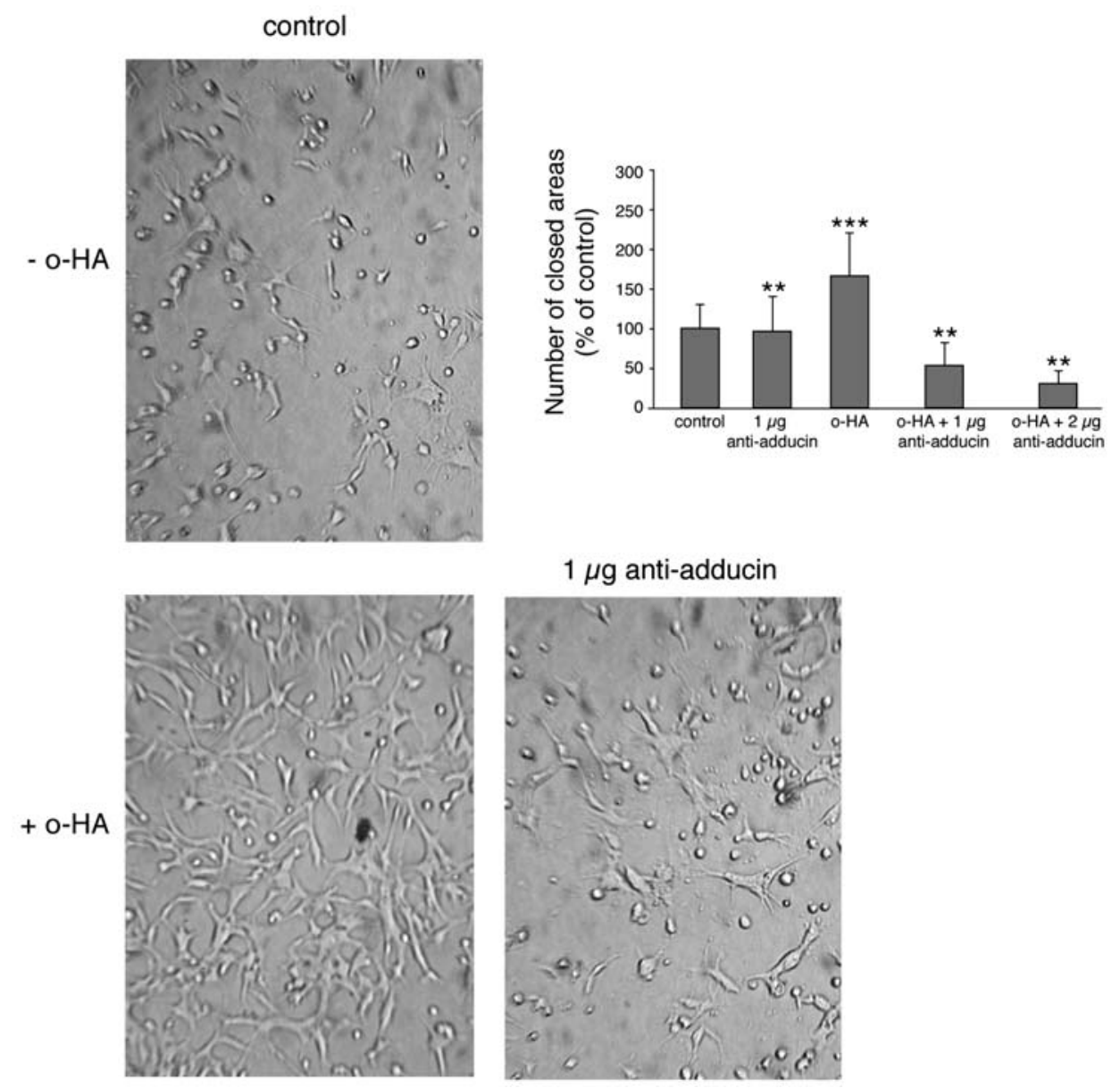

Figure 8. Inhibition of $\gamma$-adducin significantly reduced o-HA-induced endothelial tube formation. An anti- $\gamma$-adducin antibody was introduced into the cytoplasm of BAEC using the PULSin delivery reagent. Representative photomicrographs (original magnification, $\mathrm{x} 100$ ) showing increased tube formation in the presence of o-HA. When $\gamma$-adducin was neutralized of with $1 \mu \mathrm{g} \mathrm{of} \gamma$-adducin antibody, o-HA-induced endothelial tube formation was decreased compared to o-HA alone. Values represent the means $\pm \mathrm{SD}$ of three experiments. ${ }^{* *}$ and ${ }^{* * *}$ signify a statistically significant difference $(\mathrm{p}<0.01$ and $\mathrm{p}<0.001$, respectively) from the control.

the involvement of PKC $\alpha$ in the phosphorylation of $\gamma$-adducin, cells were treated with Go6976 (10 nM) 24 h before mixing with Matrigel (Fig. 6). There was no change in tube formation compared to the control. However, in the presence of o-HA a reduction of $\mathrm{O}-\mathrm{HA}$ induced tube formation was observed (Fig. 6A). After the Matrigel assay, the medium was collected and MMP activities determined. An inhibition of o-HAinduced MMP-9 activity but no change in that of MMP2 was demonstrated after treatment with Go6976 (10 nM, Fig. 6B). Together, these data suggest a role for PKC- $\alpha$ in the phosphorylation of $\gamma$-adducin and subsequent regulation of MMP-9 activity in o-HA-induced tube formation in Matrigel.

Involvement of CD44/phospho- $\gamma$-adducin in o-HA-induced $F$-actin cytoskeleton rearrangement. The effect of o-HA on the distribution of phospho- $\gamma$-adducin and of F-actin stress fibres in siRNA-treated cells was visualised by immunofluorescent staining. A diffuse peri-nuclear distribution of phospho- $\gamma$-adducin with few F-actin stress fibres was observed in both NC siRNA and RHAMM siRNA-treated cells (data not shown). In CD44 siRNA-treated cells the same diffuse distribution of phospho- $\gamma$-adducin was observed but the stress fibres were organised in parallel giving the EC an elongated shape (Fig. 7). On addition of o-HA, an increased expression of phospho- $\gamma$-adducin was observed in control, NC siRNA-treated and RHAMM siRNA-treated cells (data not shown) with more intense F-actin stress fibres arranged in spike-like protrusions resembling microvilli-like structures along the cell membrane. After CD44 knock-down cells showed a much weaker expression of phospho- $\gamma$-adducin, a more elongated cell shape and disappearance of F-actin stress fibres (Fig. 7). These observations suggest that CD44 is involved in F-actin cytoskeleton rearrangement through the regulation of phospho- $\gamma$-adducin expression.

Involvement of $\gamma$-adducin in o-HA-induced in vitro angiogenesis. To investigate an involvement of $\gamma$-adducin with the pro-angiogenic effects of o-HA, anti- $\gamma$-adducin antibody ( 1 and $2 \mu \mathrm{g}$ ) was introduced to the cytoplasm of BAEC (Fig. 8). The reagent formed non-covalent complexes with R-phycoerythrin-labelled antibody and the majority of transfected cells contained the fluorescent protein (data not shown). The antibody alone had no significant effect on the number of closed areas in Matrigel compared to the control. However, on addition of o-HA the antibody ( 1 and $2 \mu \mathrm{g} / \mathrm{ml})$ produced a significant decrease of tube formation (51 and 65.5\%; $\mathrm{p}<0.05$ in both cases) compared to o-HA alone. These results demonstrate a role for $\gamma$-adducin in o-HA-induced tube formation. 


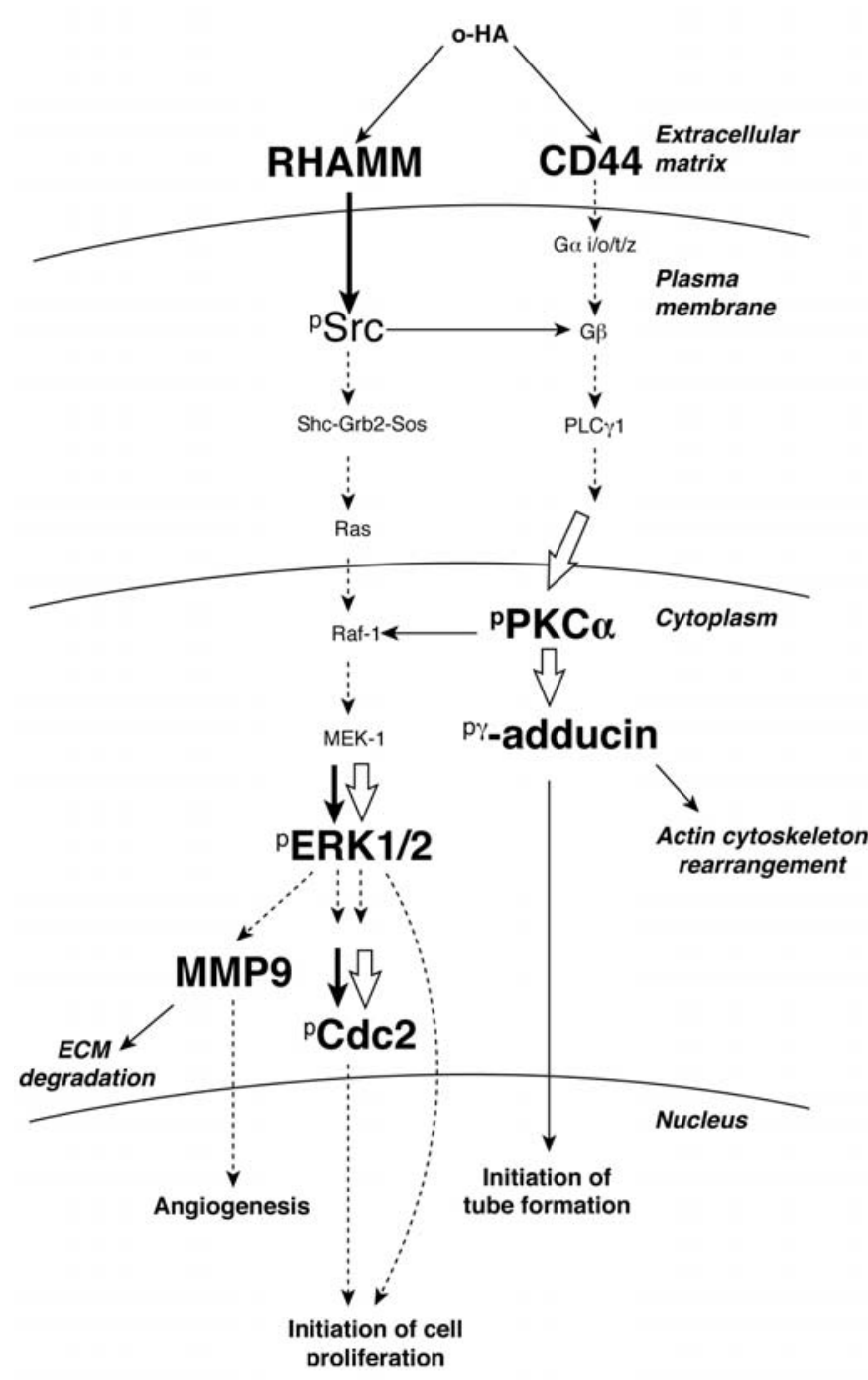

Figure 9. A schematic representation of the signal transduction pathway associated with o-HA induced EC tube formation and proliferation. The intermediates in bold were identified in the current study. Abbreviations as used in the text.

\section{Discussion}

Gene knockdown. In order to investigate a role in o-HAinduced EC tube formation we knocked down the CD44 and RHAMM gene and protein expression using siRNA and identified down-stream second messengers. The specificity of the knock-down was assessed using EGF as a positive control since its receptor-mediated binding and signalling pathways are not linked directly to HA or HA receptors in EC (25). CD44, a member of the hyaladherins comprises a family of transmembrane glycoproteins with an extracellular domain capable of binding HA and a cytoplasmic tail which regulates specific signalling pathways and reacts with cytoskeletal proteins (17). Specifically, CD44v3/RhoA complex has been shown to stimulate Rho kinase (ROK) and promote phosphorylation and binding of CD44 variants to ankyrin or ERM (26). This may contribute to tumour cell migration and the progression of cancer (27). RHAMM also binds HA and plays a central role in the assembly of the cytoskeleton perhaps by connecting actin and the mictotubule cytoskeleton (17).
Protein phosphorylation. Using a Kinexus phospho-protein screen we showed up-regulation of five proteins ERK1/2, Cdc2, PKC- $\alpha$, GSK-3b and $\gamma$-adducin in o-HA treated siRNA knockdown EC. $\gamma$-addducin, a membrane-cytoskeletal protein which binds actin filaments and promotes their interaction with spectrin in the formation of the cytoskeleton was selected for further study (28). We showed o-HA binding to CD44 but not RHAMM induced a PKC- $\alpha$-induced increase in phospho$\gamma$-adducin expression and $\mathrm{F}$-actin cytoskeletal rearrangement resulting in a change of cell shape. CD44 knock-down also prevented the formation of o-HA-induced actin stress fibres. Phosphorylation by PKC is known to be important for dissociation of spectrin from the actin cytoskeleton and is important in determination of cell shape and movement (29). Using a specific inhibitor of PKC, we showed that PKC- $\alpha$ which has a central role in angiogenesis was involved in o-HAinduced endothelial tube formation in Matrigel. In PKC- $\alpha$ knockout cells, Wang et al, demonstrated inhibition of endothelial tube formation in a 3-D collagen gel and also inhibition of myocardial neovascularisation in vivo (30). Moreover, using anti-sense PKC- $\alpha$ a reduction of secretion of MMP-9 through the ERK1/2 pathway in capillary endothelial cells has previously been observed (31). These data are in agreement with our findings and suggests that activation of these signalling intermediates form an important part of the pathway associated with o-HA-induced tube formation through the CD44 receptor.

CD44 and cytoskeletal rearrangement. We showed that after CD44 knock-down a rearrangement of the actin cytoskeleton occurred giving an elongated shape to the cells in the absence of o-HA, whilst CD44 knock-down prevented the formation of actin stress fibres induced by o-HA. Recently, PKC has been shown to have a role in the regulation of actin cytoskeleton (reviewed in ref. 32) and to be responsible for activating ezrinradixin-moesin (ERM)-mediated crosslinking between CD44 and the actin cytoskeleton (33). Furthermore, Kalomiris and Bourguignon (34) showed that the interaction between CD44 and actin filaments may be mediated though an ankyrin-like protein which could bind to actin-binding proteins such as adducin, like found in erythrocytes. Therefore, the inhibition of o-HA-induced actin stress fibre formation in CD44 siRNAtreated cells could be explained by the lack of phosphorylation of PKC- $\alpha$; however, further studies need to be undertaken in order to fully understand the intracellular mechanisms responsible for formation of these morphologically distinct or 'polarised' cells associated with CD44 knock-down.

Matrix metalloprotein activation and receptor binding. MMP-2 is known to degrade type IV collagen, the major component of the basement membrane and is important for promotion of angiogenesis in vivo and in vitro where it has also been shown to bind to $\alpha_{5} \beta_{3}$ integrin, stimulate production of other angiogenic factors, and form multi-protein complexes in the focal adhesions of migrating vascular EC (reviewed in ref. 14). Here, for the first time, we have demonstrated increased MMP-9 activity associated with o-HA-receptor binding in vascular EC. Inhibition of PKC- $\alpha$ using Go6976 also inhibited MMP-9 activity and subsequent o-HA-induced tube formation in Matrigel suggesting it could be important 
in modulating the angiogenic process. Fieber et al (35) showed the presence of a similar pathway in primary fibroblasts and showed that o-HA but not high-molecular-weight HA induced MMP-9 transcription mediated through both CD44 and RHAMM. Further work should examine whether MMP-2 is associated with other components of angiogenic signalling pathways including integrin-mediated inside-out cell signalling or formation of focal adhesions in migrating cells. The involvement of $\mathrm{Cdc} 2$ in o-HA-receptor mediated signalling and angiogenesis is novel, although perhaps not surprising. Cdc2 inhibition with roscovitine is known to prevent cell mitosis (36), and earlier studies of Mohapatara et al demonstrated that dominant negative RHAMM mutants or antisense mRNA-mediated down-regulation of RHAMM, was sufficient to decrease Cdc2 protein levels and inhibit mitosis (37). However, it is useful to have identified one of the penultimate signalling intermediates involved in promotion of o-HAinduced mitogenesis

In summary, we have identified novel components of the down-stream angiogenic signalling pathways associated with both CD44 and RHAMM-mediated tube formation in vascular EC. In particular, o-HA-induced vascular EC tube formation is partly dependent on CD44-mediated signalling through a pathway involving PKC- $\alpha$ and $\gamma$-adducin. The complete roles of Cdc2 and MMP-9 have yet to be determined. Knowledge of the mechanisms through which o-HA induces neovascularization could help in defining new treatments for modulation of angiogenic diseases.

\section{Acknowledgements}

We thank Mr. M. Hoult for the preparation of the figures.

\section{References}

1. Folkman J: Angiogenesis: an organizing principle for drug discovery. Nat Rev Drug Discov 6: 273-286, 2007

2. West D and Kumar P: Hyaluronan and angiogenesis. Ciba Found Symp 143: 187-220, 1989.

3. West DC, Hampson IN, Arnold F and Kumar S: Angiogenesis induced by degradation products of hyaluronic acid. Science 228: 1324-1326, 1985.

4. Rooney P, Kumar S, Ponting J and Wang M: The role of hyaluronan in tumour neovascularization (review). Int $\mathrm{J}$ Cancer 60: 632-636, 1995.

5. Wang DY, Kao CH, Yang VC and Chen JK: Glycosaminoglycans enhance phorbol ester-induced proteolytic activity and angiogenesis in vitro. In Vitro Cell Dev Biol Anim 30: A777-A782, 1994.

6. West DC and Kumar S: The effect of hyaluronate and its oligosaccharides on endothelial cell proliferation and monolayer integrity. Exp Cell Res 183: 179-196, 1989.

7. Deed R, Rooney P, Kumar P, Norton JD, Smith J, Freemont AJ and Kumar S: Early-response gene signalling is induced by angiogenic oligosaccharides of hyaluronan in endothelial cells. Inhibition by non-angiogenic, high-molecular-weight hyaluronan. Int J Cancer 71: 251-256, 1997.

8. Slevin M, Krupinski J, Kumar S and Gaffney J: Angiogenic oligosaccharides of hyaluronan induce protein tyrosine kinase activity in endothelial cells and activate a cytoplasmic signal transduction pathway resulting in proliferation. Lab Invest 78: 987-1003, 1988.

9. Slevin M, Kumar S and Gaffney J: Angiogenic oligosaccharides of hyaluronan induce multiple signaling pathways affecting vascular endothelial cell mitogenic and wound healing responses. J Biol Chem 277: 41046-41059, 2002.
10. Rahmanian M, Pertoft H, Kanda S, Christofferson R, ClaessonWelsh L and Heldin P: Hyaluronan oligosaccharides induce tube formation of a brain endothelial cell line in vitro. Exp Cell Res 237: 223-230, 1997.

11. Rooney P, Wang M, Kumar P and Kumar S: Angiogenic oligosaccharides of hyaluronan enhance the production of collagens by endothelial cells. J Cell Sci 105: 213-218, 1993.

12. Slevin M, Krupinski J, Gaffney J, Matou S, West D, Delisser H and Savani R: Hyaluronan-mediated angiogenesis in vascular disease: uncovering RHAMM and CD44 receptor signalling pathways. Matrix Biol 26: 58-68, 2007.

13. Ponta H, Sherman L and Herrlich PA: CD44: from adhesion to signalling regualtors. Nat Rev Mol Cell Biol 4: 33-45, 2003.

14. Van Hinsberg VW, Engelse MA and Quax PH: Pericellular proteases in angiogenesis and vasculogenesis. Arterioscler Thromb Vasc Biol 26: 716-728, 2006.

15. Day AJ and Prestwich GD: Hyaluronan-binding proteins: tying up the giant. J Biol Chem 277: 4585-4588, 2008.

16. Thorne RF, Legg JW and Isacke CM: The role of CD44 transmembrane and cytoplasmic domains in co-ordinating adhesive and signalling events. J Cell Sci 117: 373-380, 2004.

17. Turley EA, Noble PW and Bourguignon LY: Signalling properties of hyaluronan receptors. J Biol Chem 277: 4589-4592, 2002.

18. Hall CL, Lange LA, Prober DA, Zhang S and Turley EA: Hyaluronan and the hyaluronan receptor J Cell Biol 126: 575-588, 1994.

19. Assmann V, Jenkinson D, Marshall JF and Hart IR: The intracellular hyaluronan receptor RHAMM/IHABP interacts with microtubule filaments. J Cell Sci 112: 3943-3954, 1999.

20. Zhang S, Chang MC, Zylka D, Turley S, Harrison R and Turley EA: J Biol Chem 273: 11342-11348, 1998.

21. Sattar A, Rooney P, Kumar S, Pye D, West DC, Scott I and Ledger P: Application of oligosaccharides of hyaluronan increases blood vessel numbers in rat skin. J Invest Dermatol 103: 576-579, 1994.

22. Elbashir SM, Harborth J, Weber K and Tuschl T: Analysis of gene function in somatic mammalian cells using small interfering RNAs. Methods 26: 199-213, 2002.

23. Matou S, Colliec-Jouault S, Galy-Fauroux I, Ratiskol J, Sinquin C, Guezennec J, Fischer AM and Helley AD: Effect on oversulphated exopolysaccahrides on angiogenesis induced by basic fibroblast growth factor-2 or VEGF in vitro. Biochem Pharmacol 69: 751-759, 2005.

24. Angulo J and Matou S: Application of mathematicalk morphology to the quantification of in vitro endothelial cellorganisation into tubular-like structures. Cell Mol Biol 53: 22-35, 2007.

25. Ellis IR, Schor AM and Schor S: EGF and TNF-alpha motogenic activities are mediated by the EGF receptor via distinct matrix-dependent processes. Exp Cell Res 313: 732$741,2007$.

26. Goueffic Y, Guilluy C, Guerin P, Patra P, Pacaud P and Loirand G: Hyaluronan induces vascular smooth muscle cell migration through RHAMM-mediated PI3K-dependent Rac activation. Cardiovasc Res 72: 339-348, 2006.

27. Oliferenko S, Kaverina I, Small JV and Hube LA: Hyaluronic binding to CD44 activates RAC1 and induces lamelopodia outgrowth. J Cell Biol 148: 1159-1164, 2000.

28. Chen CL, Hsieh YT and Chen HC: Adducin regulation. J Cell Sci 120: 1157-1167, 2007.

29. Matsuoka Y, Hughes CA and Bennett VJ: Definition of the calmodulin-binding domain and sires of phosphorylation by protein kinases A and C. J Biol Chem 271: 25157-25166, 1996.

30. Wang A, Nomura M, Patan S and Ware JA: Inhibition of protein kinase $C$ alpha prevents endothelial cell migration and vascular tube formation in vitro and myocardial tube formation in vitro and myocardial vascularisation in vivo. Circ Res 90: 609-616, 2002.

31. Park MJ, Park IC, Lee HC, Woo SH, Lee JY, Hong YJ, Rhee CH, Lee YS, Lee SH, Shim BS, Kuroki T and Hong SI: Protein kinase alpha activation by phorbol ester inducers secretion of gelatinase B/MMp9 through ERK $1 / 2$ pathway in capillary endothelial cells. Int J Oncol 22: 137-143, 2003.

32. Larsson $C$ : Protein kinase $C$ and the regulation of the actin cytoskeleton. Cell Signal 18: 276-284, 2006. 
33. Jensen PV and Larsson LI: Actin microdomains on endothelial cells: association with CD44, ERM proteins and signalling molecules during quiescence and wound healing. Histochem Cell Biol 121: 361-369, 2004

34. Kalomiris EL and Bourguignon LY: Mouse T lymphoma cells contain a glycoprotein (GP85) that binds ankyrin. J Cell Biol 106: 319-327, 1998

35. Fieber C, Baumann P, Vallon R, Termeer C, Simon JC, Hofmann M, Angel P, Herrlich P and Sleeman JP: Hyaluronan oligosaccharide-induced transcription of metalloproteinases. J Cell Sci 117: 359-367, 2004.
36. Qiao M, Shapiro P, Fosbrink M, Hus H, Kumar R and Passaniti A: Cell cycle-dependent phosphorylation of the RUNX2 transcription factor by $\mathrm{Cdc} 2$ regulates endothelial cell proliferation. J Biol Chem 28: 7118-7128, 2006.

37. Mohapatra S, Yang X, Wright JA, Turley EA and Greenberg AH: Soluble hyaluronan receptor RHAMM induces mitotic arrest by suppressing Cdc2 and cyclin B1 expression. J Exp Med 183: 1663-1668, 1996 